\title{
研究を通した国際協力で求められる水文科学の役割と方法論
}

\author{
杉田 倫明 ${ }^{1 *}$
}

\section{International Collaboration and Cooperation through Researches of Hydrologic Science}

\author{
Michiaki SUGITA $^{1 *}$
}

\begin{abstract}
As water is essential to life on Earth and it also acts as an agent to influence environments, knowledge of hydrologic science is often needed to seek out solutions to many practical problems. As such, researches of hydrologic science have expanded their target not only within Japan but also in many parts of the world. Unfortunately, international cooperation through such activities has not always been successful, particularly in areas outside researches such as technology transfer and capacity development, even though such contributions to society at local, national and international levels are desirable and have even been required particularly in recent years. It is argued that lack of our experience and knowledge in such areas is one of the causes that prevent our efficient involvement and achievement in international cooperation. Since this article is mainly based on personal experiences and on limited data and statistics, a more thorough investigation is clearly needed.
\end{abstract}

Key words: Mongolia, Egypt, international cooperation, hydrologic science

I . はじめに

田中（2009）によると，水文科学とは，「水循 環を中心概念として，自然界における水のあり 方，水量と水質，循環プロセス，水と環境との関 係，人間と水とのかかわりなどを系統的に理解す るための科学」である。この定義に従えば，水に 係わる極めて広い現象が対象に含まれる。特に 「人間と水とのかかわり」や「水と環境との関係」 の部分は，前半の基礎科学的な部分と対をなして おり, 基礎科学であると捉えられがちな水文科学 が，実は応用的な側面をも含んでいるという点を 忘れるわけにはいかない。すると，水文科学が果 たせる，あるいは果たすべき研究を通した国際協
力というのは，極めて広範に及ぶと思われる。そ して，この問題をきちんと整理して取り組むに は, 先行研究 (事例) をレビューし, 問題点を取 り上げ，考察を深め，改善点を探っていく，とい う道筋を辿るのが筋であろう。しかし，これまで その様な取り組みは行われていないようである。 本稿も，そのような網羅的な取り組みは意図して はいない。どちらかと言えば，極めて限られた個 人的な経験を基にした考察である。今後，より包 括的かつ系統的な検討が行われることを期待し て，その足がかりになるような情報の提供，考察 を心がけた。具体的には，ここ 10 年ほどの研究 対象地域としてきたモンゴルやエジプトでの経験 を基に，水文科学は海外での研究現場で何を求め

1 筑波大学生命環境系・水文科学リサーチユニット Research Unit on Hydrologic Science, Faculty of Life \& Environmental Sciences, University of Tsukuba 
られているのか，何が出来るのか，そして，海外 での研究でほぼ必ず課題にあがる技術移転や社会 貢献などを通じた国際協力のあり方について考え をまとめてみたいと思う。

\section{II. 水文科学は海外協力で求められているのか}

一般論として，海外が舞台の多くの課題で水文 科学の知識は必要不可欠と言ってもよい。人間が 水を必要とする生物である以上，水を抜きにして は，解決出来るものも出来なくなる場合が多いか らである。たとえば，自然災害の発生件数の半分 弱は水が何らかの形で関係している（杉田, 2012）。世界の人口増加と食糧生産量の増加を今 のところ支えているのは，化学肥料の使用（施肥 量の増加）や灌溉耕地面積の拡大（たとえば, $\mathrm{FAO}, 2011 ） て ゙ あ り ，$ 水の確保が重要な意味を持 つ。また，近年，経済的な観点から注目される水 ビジネス（杉田，2010）や水文科学とは縁遠乞 うな感染症の問題もまた，水が梁く関わってい る。上下水道の整備と衛生に係わる問題では，水 道水源（原水）としてどこを選ぶか，乾期にしば しば負圧になってしまう水道管への地中水を介し た污染物質や病原体の侵入問題（たとえば，奥 沢・濱田，2000）など，水文科学の知識が有用 な場面が多いように思われる。また，八マダラカ を媒介して感染するマラリア対策では，八マダ ラカの発生源となる表層水の存在時期や範囲が 重要な情報である（たとえば，Bomblies et al., 2008）。日本国の政府開発援助でも「水と衛生」 (菅原，2000），「防災・災害復興」「環境」など の分野が大きな ODA（Official Development Assistance）額となっている（Fig. 1，外務省国際 協力局，2014）。

一方，研究という点に焦点を絞ると，たとえ ば，審査基準「海外学術調査」（主たる目的が国 外の特定地域におけるフィールド調査，観測又は 資料収集を行うものが対象）による日本学術振興 会の基盤研究 $\mathrm{A} \cdot \mathrm{B}$ で採択された課題の中で, (「淡水ザメ」など明らかに本稿の趣旨と関係がな

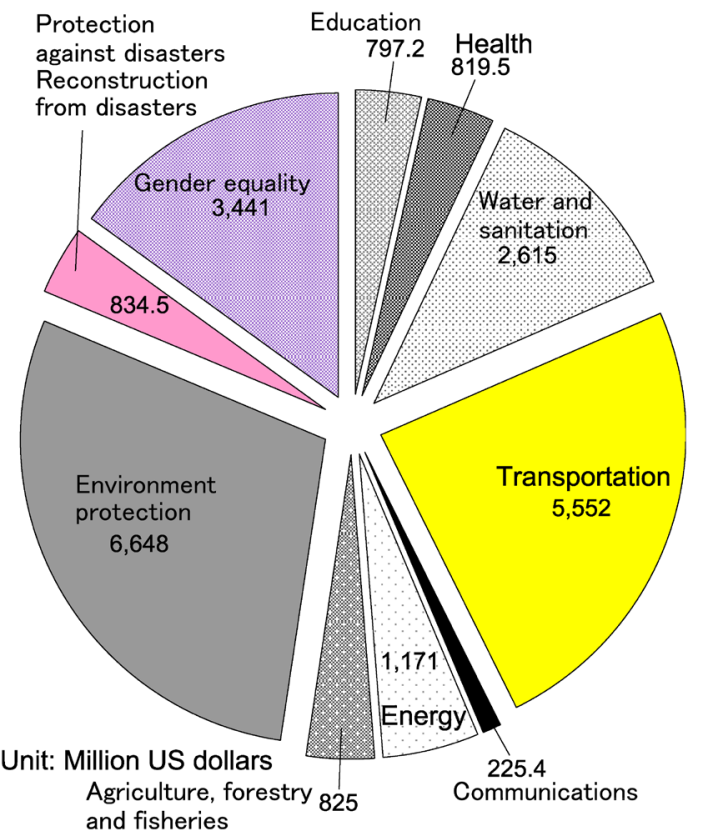

Fig. 1 Breakdown of the project budget of the bilateral official development assistance of the Government of Japan by sector (based on the International Cooperation Bureau, Ministry of Foreign Affairs of Japan (2014)). Unit of the figure is million US dollars. Minor items are not indicated.

いものを除く）「水」が課題名に含まれる課題は， 2009-2010年度で，19/530 =4\%（新規課題のみを 対象)，1963-1995年度を対象にすると 68/4228= 2\%（新規十継続課題合計）となる（国際学術研 究調査関係研究者データベース, 科学研究費補助 金 (海外学術調査) 採択課題一覧 (海外学術調査 総括班，2014）による)。意外に割合が少ないと 感じるかもしれないが，科学研究費補助金の対象 が人文科学や社会科学など極めて広い分野を含む ことから，ある意味では当然なのかもしれない。

一方，現在の大型研究予算の中でも特に国際を 前面に出した科学技術振興機構（JST）と国際協 力機構 (JICA) が共同で実施している「地球規 模課題対応国際科学技術協力プログラム (SATREPS)」には「環境・エネルギー（気候変動領 域)」「環境・エネルギー (低炭素社会)」,「環 境・エネルギー (地球規模の環境課題)」「生物資 


\section{研究を通した国際協力で求められる水文科学の役割と方法論}

源」「防災」「感染症」の研究領域があるが，全て を通して「水」が課題名に入った研究プロジェク 卜は 89 件中 11 件 $(12 \%)$ である（科学技術振興 機構，2014）。課題名に入っていなくても水が重 要なテーマのものもある。たとえば，以下に事例 としてとりあげる「ナイル流域における食糧・燃 料の持続的生産（代表：佐藤政良筑波大学名誉教 授)」の副題は「限りある水資源を食糧問題の解 決に!」である。課題名には現れないが，水が主 要テーマである。

\section{III . 水文科学の研究を介した国際協力は うまくいっているのか}

\section{1. どのような国際協力があるのか}

水文科学が研究面の国際協力で求められている のは確かであるが，うまくいっているのだろう か。この点を考えるには，ふたつの場合に分け て扱うのが良いように思われる。ひとつは，研究 そのもの，もうひとつは，研究から波及するはず の国際協力である。

研究そのものについては，得られた結果を論文 として公表する, という部分については，概略う まくいっているのではないか。しかし，様々な問 題点が含まれている可能性もある。たとえば，以 下のような視点が大事であろう。

（1）日本人が現地に乗り込んで，自分たちだ けでデータを取って結果を出していないか？

（2）現地で行われていた既存研究を無視して いないか

（3）得られた結果を現地に還元できている か?

一方，研究の波及効果の部分に注目すると，

（4）研究が役に立ったのか？そうであれば， それはどのような場面（たとえば，政策立案， 人材育成，技術移転，あるいはそれ以外など） なのか。

という点が気になるところであろう。上で述べた と打り，水文科学を対象として包括的にこの問題 を調べた取りまとめは存在しないようである。一
方，自分自身の経験からすると，どの項目も，あ まり自慢できる状態ではないように感じる。たと えば，(1）は相手国で自分の研究分野と重なり があり，しかも研究能力を併せ持つ研究者を見い だせるかにかかっているが，特に先端的な研究手 法を用いようとすると，そのような研究者を見い だすことは先進国以外では極めて難しい。発展途 上国だと，どうしても関連分野で興味の近い人と いう程度で妥協することになりがちである。(2) は言語の問題と研究の方法論が共有できているの かが往々にして障壁となる。現地語で書かれた文 献は，相手国側の共同研究者の協力なしでは見つ けられない。従って（1）と密接に関わってい る。さらに，文献が見つかったとして，現在，一 般的に受け入れられている科学論文の体裁が整つ ていない論文に遭遇する場合が多いが，それをど う扱ったら良いのかである。たとえば，研究方法 が具体的に記されていないため, 結果をどう評価 して良いのか判断に苦しむ，文言として記述して あることを具体的に示す数字，グラフや表がな い，などである。（3）から（4）については，具 体的な成果が見えにくいのが実感である。そこに はもちろん国際協力には研究とは別の面の難しさ があるからなのだろう。以下，筆者が係わった事 例を用いて，より具体的な点を考えてみたい。

\section{2. 事例 (1) モンゴル}

この事例は, JSTの戦略的創造研究推進事業 （CREST）の枠組みで 2003 年〜2007年にかけて 実施された研究領域「水の循環系モデリングと利 用システム」の中の研究課題「北東アジア植生変 遷域の水循環と生物・大気圈の相互作用の解明」 である。相手国側研究機関は, Institute of Meteorology and Hydrology (IMH, 現 : Research and Information Institute of Meteorology, Hydrology, and Environment) と Education and Research Institute ECO Asia大学で，それぞれ研 究・現業機関と教育機関であり，モンゴル北東部 を対象に水循環と大気，生態系，そして人間活動 の関係を明らかにした。研究内容などは, Sugita 
et al.（2007）ほかを参照していただくとして, 以下，特に上であげた（3）（4）について実施 した内容とその効果について記す。

まず，プロジェクトに所属するモンゴル側研究 者と結果の共有をはかるために，彼らを日本に招 待して研究集会（シンポジゥム）を毎年開催した (詳細はAMPEX/IORGC/RAISE（2005）など)。 さらにプロジェクト外の一般研究者にも成果を還 元するという意味合いで，モンゴルで一般公開の シンポジゥムを開催した (Azzaya, 2005)。いず れも，モンゴルを対象にして研究内容に重なりの ある 2 プロジェクトと共同で開催することで，多 くのモンゴル側研究者を日本に招待することがで きた。

同様に，上記（3）から（4）に位置づけられ る活動として，3言語版研究成果ハイライト集 (RAISE 研究チーム, 2007a, 2007b, 2007c) と 取得全データのDVD (Sugita et al., 2008) 作 成，配布をあげることが出来る。前者は，水文科 学などを専門としない (公務員, 政治家や小中学 校の教員など）を対象として想定し，モンゴル人 はモンゴル語版，英語版の原稿を，日本人は，英 語版，日本語版を作成し，欠けている言語版を翻 訳する形で 3 言語版が作成された。ハイライト集 についてはモンゴル国内の主要研究機関や関係省 庁などに配布してもらった。モンゴルの場合，研 究者が閣僚になることも十分あり得る（IMHの 元所長が自然環境大臣や駐日モンゴル国大使に なった例もある）ので，多少違う分野の研究者に 配布することも意味があろうと考えた。DVDの データセットは，主にモンゴルの研究者，教員を 対象に，データを有効活用してもらう目的で作成 され，ハイライト集と同様に配布した。なお，通 信事情が制約にならない国向けには，最新版 （RAISE，2015）をネットワーク上でも公開して いる。

このような活動は，短期的，あるいは長期的に 何かの役に立ったのだろうか。実は検証を行う機 会もなく，また，具体的にこういう成果が数字と してあげられる，といったこともない。直感的に
は，直ぐに役に立ったことはあまりないような気 がするが，プロジェクト終了後に Honorable Researcher Award (Ministry of Nature and Environment of Mongolia）という名誉ある賞を頂い たので，局所的には何か役に立てたのかもしれな い。しかし，役に立ったのは，どちらかと言え ば，日本側にとってという意味の方が大きかった ように思われる。たとえば，共同研究を通した人 的ネットワークの形成は, 以後のモンゴルでの (別枠の) 研究をスムーズに進めるのに大変役に 立ったことは確かである。UNESCO Chair on Sustainable Groundwater Management in Mongolia (UNESCO, 2015) が Institute of Geoecology (Mongolian Academy of Sciences) と筑 波大学に 2007 年に設置されたのもこの流れの 1 つである。また，このプロジェクト終了後に開始 された総合地球研究所のプロジェクト「人間活動 下の生態系ネットワークの崩壊と再生プロジェク ト」(2006-2012年, Yamamura et al., 2013な ど参照) でのモンゴル研究も機材の設置から非常 にスムーズにすすめられた。なお，このプロジェ クトは，文系，理系研究者が協力するいわゆる文 理融合型ということもあり, 成果は学術図書の形 でまとめられている。日本語版が藤田ほか (2013)，モンゴル語版がБатжаргал et al., 2012) であり, やはりモンゴルで開催されたシンポジゥ ムでの直接配布のほか，関係機関に配布されてい る。

最後に，このプロジェクトの中で最も大きな成 果だと個人的に考えているのは，次世代の研究者 の育成である。このプロジェクトの係わりで, Education and Research Institute ECO Asia大 学の学部卒の教員が日本政府の国費留学生として 筑波大学に受け入れられ，修士号，博士号を取 得，無事帰国し，現在モンゴル国立大学の教員を している。わずか 1 名であるが，彼が次の世代の 学生をきちんと育て，さらにその次が…と続くの が理想である。おそらくこのような地道な活動を 続けていくことではじめて，発展途上国との共同 研究がスムーズに進むようになるのではないか。 
研究資金や設備はある程度は日本側から投入でき るが，それを活用できる人材がいないことには， 宝の持ち腐れとなりかねない。

\section{3. 事例 (2) エジプト}

この事例は，前述のSATREPSの枠組みで実 施された「ナイル流域に打ける食糧・燃料の持続 的生産」プロジェクト (2009-2015年) で，人 口増加，ナイルデルタ外の砂漠地域に打ける新規 農地開拓を背景に, ナイル川の水に頼ってきた工 ジプト農業が近い将来の水不足に対処する方法を 考えようという内容で，そのための調査研究を実 施するが，それだけではなく，政策提言というよ うな，より国際協力的な内容が目的に含まれてい る。 Faculty of Agriculture (Cairo University), National Water Research Center, Agriculture Research Centerの3機関を共同研究機関として プロジェクトが実施された。

上のCRESTの事例と異なるのは, SATREPS が JSTのみではなくJICAが共同で運用している 点である。おそらくそのためと考えられるが，国 際協力をすすめる枠組みが, SATREPSの中に用 意されていた。たとえば，相手国研究者・技術者 に対する日本での研修が予算的に保証されてお り, 具体的には研究開始 $2-3$ 年目をめどに毎年 1 カ月程度，8-9名を研修のために日本に招へいし た。私の担当であった渦相関法による蒸発量測定 と解析についても 3 研究機関それぞれから各 1 名, 合計 3 名の研究者に来日してもらい, 内 2 名 については，専門分野がやや離れていたこともあ り, 微気象学的な内容の講義から, 実際の測定, データ処理まで，研修を実施した。しかし，1カ 月という期間は，全く知識のないものに実用レべ ルまでの技術を身につけてもらうには，残念なが ら十分ではないと感じた。実際，研修を受けた研 究者が帰国後にその技術を利用出来たかという と，せいぜい $30 \%$ 程度というところのように思 われた（Photo 1)。技術の背景となっている理論 まできちんと身につけてもらうとすると，やは り, 大学院生などの身分である程度の期間, 滞在

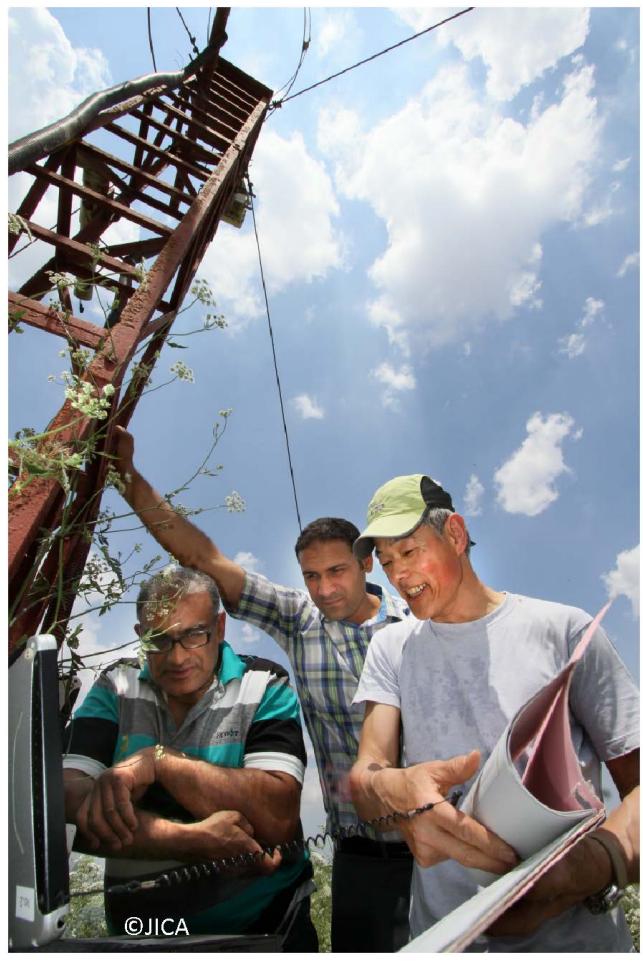

Photo 1 Working together with Egyptian colleagues in a field in Egypt (Experiemental Farm of Argicultural Research Center in Sakha, Egypt, 2014/5/11). Even after the technical training in Japan, on-the-job training was necessary.

してもらうしかない。また，研修を受けに来る研 究者の動機も問題なのかもしれない。短期間なの で，どちらかと言えば観光旅行的なことを考えて いた可能性も高い。彼らにとっては，それでも履 歴書に日本での研修参加を載せることができるの で，どこかで有利に働くのだろう。共同研究者の 選択の段階で，多くの候補者の履歴書に目を通し たが，研修という項目に長いリストが含まれてい るのが一般的であった。

このプロジェクトでも，エジプト側研究者を招 待して日本国内で開催したシンポジウムに加え て，エジプトでもシンポジウムを開催した。ま た，個別の論文発表以外に，全体をまとめた英語 の書籍の公表準備が進んでいる。現地での会合開 催に扔いては，各機関の上層部などにも声がかけ 
られ，実際に一部でも参加してくれている。そし て新聞報道などを念頭に，会合の開催をメディア 関係にも広報していた。このあたりのノウハウは 業務調整員（Project Coordinator；現地の事情 に詳しく，アラビア語を話すことが出来る日本人 を雇用）やJICAの現地事務所に負うところが大 きい。また，調整員以外に，事務処理，技術面で それぞれエジプト人が雇用された。戋場管理など を担当した技術面のアシスタントは，修士号をと る前後の学生で，雇用期間中に修士号を取得した ものも多い。また，そのうちの一名は，プロジェ クト終了間際に，日本国の国費留学生として，プ ロジェクト参加大学の 1 つである鳥取大学への留 学が決まり, 博士号取得に向けて, 研究が始まっ たところである。

前述の通り，政策提言などが目的に含まれてい たこともあり，プロジェクトの最終年度には，研 究と言うよりは，国際協力に重点があったように 感じた。具体的には，得られた成果を政策提言集 として取りまとめるために，成果と提言内容を各 機関の上層部に知ってもらい意見をもらうための 会合（通称Roundtable discussion）を2日間に わたり開催し，また，最終シンポジウムの場で研 究報告の他に，政策提言の枠を設けたこと，政策 提言と今後の研究の方向性を示す政府への提言 （Satoh, 2015）を印刷物としてまとめ，提出した ことなどが目新しいところであった。その効果が どの程度なのかはなかなか判断に苦しむが，少な くとも好意的な反応であったと聞いている。

日本の政府開発援助は大きな「もの」をつくる ことが中心，という印象を持っていたが，それだ けではない。実際は小回りのきく小さなもの，そ してそれに付随した技術の移転がセットになって いるのだという（長田，2014，私信）。このプロ ジェクトでは，JICAの資金で購入した物品は, プロジェクト終了後にエジプト側に引き渡され た。有効に活用できるようにするための技術移転

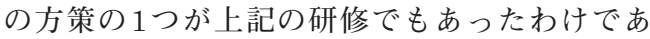
る。渦相関法のシステムに関しては，相手側の要 望，業務調整員のアドバイスなどから，プロジェ

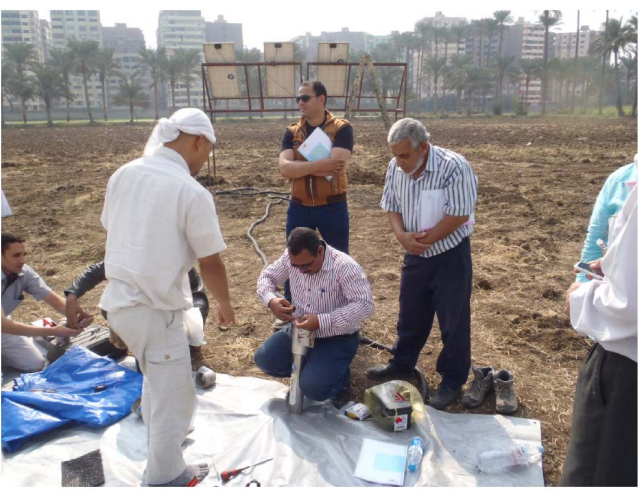

Photo 2a A photo during a training session in Egypt to learn how to carry out maintentance jobs of an eddy correlation system including sensors and data loggers. (Cairo University Experiemental Farm in Cairo, 2014/11/12).

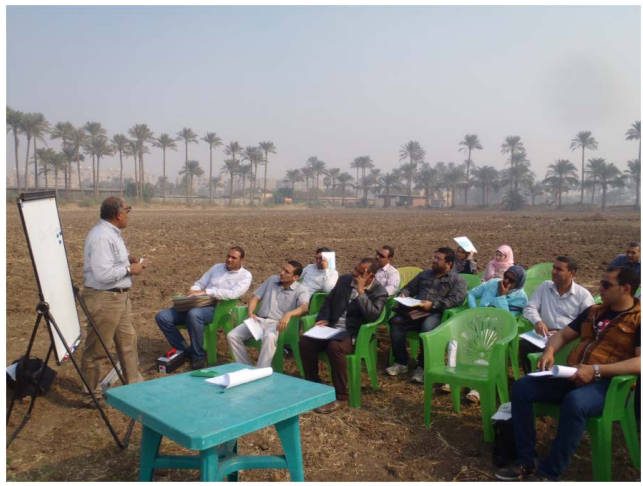

Photo $2 \mathrm{~b}$ A photo during a training session in Egypt (Cairo University Experiemental Farm in Cairo, 2014/11/12). Dr Rushdi of Cairo University is giving a lecture to the participants (mainly engineers and reserachers from three institutions).

クト終了間際に，システムの消耗品の更新とメイ ンテナンス作業を行って機材を引き渡した上で, センサー類やデータロガーの利用方法の講習会を 1日かけて実施した（Photos 2a, 2b）。講師は, 日本で研修を受けた 3 名の研究員で，補足を私た ちが行った。受講者はシステム移転を受ける 3 機 関の技術者である。率直な感想としては，技術者 の方が研究者より測定機器そのものについて学ぶ 意欲が高いように感じた。エジプトのシステムで 
は，研究者は，細かい作業は担当しない。した がって，これはある意味当然なのかもしれない。 すると研修の対象は，理論は研究者，技術面は技 術者を相手にしなければならなかったのかもしれ ない。

供与物品に関しては，メインテナンスに要する 出費が期待できないことが，最大の問題であろ う。一度，故障など不具合が生じると，機器の総 額からみれば微々たる修理費用でも，先の費用を 負担する余裕はないため，機械自体が利用できな くなる可能性が非常に高い。身近なところでは, システム全体を駆動するバッテリーであるが，数 年で交換が必要になる。ところが，共同研究者に よると，どうやらその費用を所属機関が出してく れることを期待するのは望み薄らしい。実際，観 測を実施した围場には，以前海外の機関との共同 研究の際につくられたライシメータがあったが, そのデータロガーは，壞れた状態でただ置いてあ るだけであった。「メインテナンス予算から逆算 して，それ以上の機材は供与すべきではない」 （友松・桂井，2010）という意見は卓見のように 思われる。

\section{4. 知識・方法論の欠如：研究の片手間でもその 面の知識は重要}

以上，2つの事例をあげながら，研究を通した 国際協力について，実情を紹介した。全体とし て, 研究面に比べて, 波及効果としての国際協力 は，努力の割に成果は必ずしもはっきりしない, もう少しうまくやれないものか，というのが現れ てくる感想であり総括ではないだろうか。

では，国際協力が必ずしもスムーズにいかない のはなぜだろうか。ここでは知識・方法論の欠如 という側面を考えてみたい。現在, 水文科学の研 究を行っている研究者は，打气らく国際協力につ いての系統的な研修なり授業なりを受けたことが ない。大学の授業でも理学部, 農学部, 工学部と も「国際」を冠した学科なりでもない限り，その 様な内容を扱うのは希であろう。するとどうなる か。海外の研究を実施しながら，なんとか現地に
貢献しようと考えるわけだが，その方法は，個人 の知識（あるいは常識）に基づく範囲でしかあり えず，また「片手間」となってしまっているので はないか。(もちろん国際協力の専門家でもうま くいくとは限らない難しさがあることは確かであ る（たとえば，山本・山形 $(2007)$, 友松・桂井 (2010)，など)。

ところで，「常識」は異なる文化的背景を持つ 国を相手にすると，役に立たないことも多い。た とえば，約束した時間に来ない，決めた日程が守 られない。作業時間中に礼扯に長時間出かけて 帰ってこない，1日の実労時間が短く，午後遅い 時間はあてにならない，などは良く出くわす事例 であり，日本人の常識からすると許せない思いに 駆られることも多い。しかし，礼拝が優先される のは，彼らにすれば当然であろう。また，「日本 人の常識」と思っていることも，ごく最近まで日 本でも常識ではなかったという事実も，知ってい れば，異文化の受容度が増すのではないか。たと えば，大正 11 年に定められた公官庁の執務時間 は，季節ごとに異なり，夏の間は，午前 8 時から 正午まで，毎日が半ドンであったという（橋本． 栗山，2001）。日本人もまた，実労時間は割と最 近まで短かったのである。実際，夏の労働時間を 短くするのは，合理的と考えることも可能だろ う。また，オランダ人カッテンディーケは，江戸 時代末期，安政 3 年（1856 年）に日本への引き 渡しのために臨海丸を回航し (1964), その後, 航海術などの教育に携わるために 2 年間日本に滞 在したが，その際の日記（カッテンディーケ， 1964）には，約束はするけれど当てにはならな い日本人が描かれ，「最初のほどは，‥辛抱しき れなくて焦占させられたが，まもなくそれはなん の役に立たないばかりか，ただ日本人に虽われる に過ぎないことを悟った」など，現代の日本人か らすると何かの間違いではと思いたくなる記述が 見受けられる。問題は，自分たちの常識が相手の 常識とは違うという当たり前の認識を持っていな いことかもしれない。

では，どこにその様な知識や方法論は存在する 
のだろうか。たとえば，JICAには国際協力の永 年の蓄積があり，また現在進行形で世界各地の 様々な情報を集める能力があるはずである。大学 においても，国際関係学などという名称のつく学 科，学部がある。ここでは講義として，国際関 係，異文化，各地域の経済と社会といった基礎的 な知識から開発，計画といった応用的な内容まで 含まれる場合が多いようである。学会としては, たとえば，日本国際地域開発学会や国際開発学会 などがある。前者はどちらかといえば農学系，後
者は開発というキーワードでまとまった分野横断 的な色彩が比較的強いようである。水文科学の研 究者が取りかかりやすい教科書や一般教養書も数 多くまとめられており（たとえば，系統的な記述 の友松・桂井 (2010) や事例をまとめた荒木 · 井上（2009）など)，個人レベルで得た経験を俯 瞰的に考えるのに有用である。

とはいえ, 国際協力学の知識を多忙な水文科学 の研究者に求めるのは至難の業である。少しず つ，長い目で出来ることからやるしかなかろう。

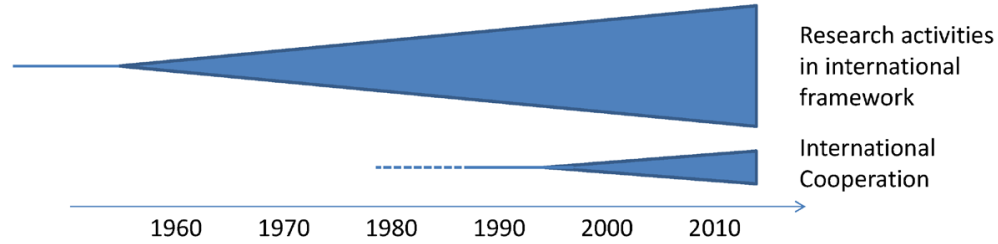

Fig. 2 Relative growth of experiences of Japanese hydrologists in researches in the international stage and that of international cooperation (y-axis: not to scale).

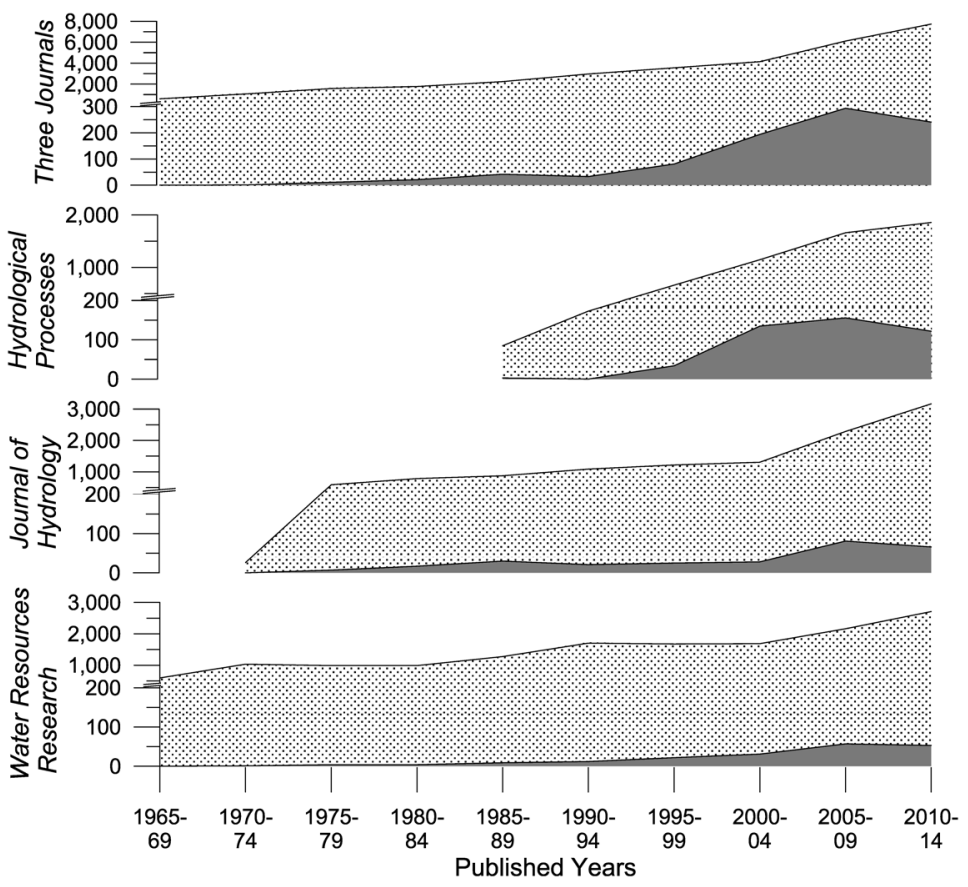

Fig. 3 The number of articles published in the Water Resources Research, the Journal of Hydrology, and the Hydrological Processes. The shaded areas indicate those published by authors whose affiliation was in Japan and the dotted areas by those outside Japan. The statistics were derived from the Web of Science database (Thomson Reuters). 
次世代の研究者の卵への教育内容や，学会の役割 の検討も大事である。

ところで, このようにしてみていくと，たどり 着く先は長く，道は険しいように感じてしまうか もしれない。打そらく，その通りだろう。制度的 な，あるいは対症療法的な方策は順次すすめるの が望ましいにしろ，根本的には，時間をかけるこ とが, 求められているのではないか。個人とし て, 分野として, あるいは社会としての経験の積 み重ねがあって, はじめて何が起きても対応でき るような, 最近の言葉を借りればレジリエンスに 富んだ水文科学を通した国際協力が出来るように なるのではないか。これについては，研究と対比 すると分かりやすいかもしれない。Fig. 2 は国際 的な枠組みの中での水文科学の研究と国際協力の 広がり，深まりを年代に対して示したものであ る。広がりの幅など, 絶対值には大きな意味は無 い。

研究に関して言うと, 現在, 得られた結果の公 表先として，まず考えるのは，国際誌と呼ばれる 世界全体に広く流通する雑誌だろう。ところが, わずか 30 年ほど前には，国際誌に投稿というの は，国内ではまだかなり珍しかった（Fig. 3)。 自分たちが大学院時代に研究結果をそういった雑 誌に投稿するようにすすめられたこともない（そ れほどの成果でなかったというのもあるわけだ が)。同様に, 国際学会に出て行って, 研究成果 を発表するのも少なくとも私の周りでは希であっ た。それが現在のように，「当然」というように なったのは，国際的な枠組みでプロジェクト研究 が行われるようになり，必然的に国際誌に投稿す ることが求められるようになったこと，投稿して みれば国内誌より受理が早い場合も往々にしてあ ること，国内開催の国際会議の特集号など，日本 人が編集を担当する場合が増えたこと，また国際 学会を国内で開催し, 英語発表をこなせる人材が 多くなってきたことなどをあげることが出来るだ ろう。特に, 最近の日本からの論文数の増加は, 2000 年から水文・水資源学会が編集を担当して 毎年発行するようになったHydrological Pro- cessesの特集号によるところが大きい。

以上，研究における国際化といった側面を，論 文，学会発表という面から見てきたが，国際協力 は研究面でのちょうど 30 年前の状態にあると見 机ば良いのではないだろうか。であれば，直ぐに うまくいかなくても，仕方がない。次世代までか かることを見据えて少しずつすすめていけば，い ずれ，研究と同じように，当たり前のこととして 水文科学を通した国際協力がすすめられるように なるのかもしれない。その意味で，大学の果たす べき役割は多い。たとえば，外務省（2013）や 国際協力機構（2015）は大学が ODAの一翼をに なうことを期待し，また実際に様々な具体化の道 筋を示している。また，文部科学省からも，大学 に対してグローバル人材育成という役割が示さ れ，予算的な裏付けがなされ出している。すなわ ち，水文科学を通した国際協力が出来るような人 材を育てる打膳立て，道具，予算といったもの は，一昔前よりは遙かに整っていると言えよう。 仕事が増える割には，人が減っているのが難点で ある。

\section{謝 辞}

丁寧に原稿を見ていただき，修正の機会を頂き ました 2 名の査読者, 担当編集委員の皆様に感謝 いたします。

\section{文献}

荒木徹也・井上 真編（2009）：フィールドから の国際協力. 昭和堂, $269 \mathrm{p}$.

奥沢英一・濱田篤郎 (2000)：開発途上国に打け

る水系感染症とその実態. 公衆衛生研究，49, 236-244.

海外学術調査総括班 (2014) : 海外学術調查総括 班. http://www.aa.tufs.ac.jp/ gisr（2014年 10 月 2 日閲覧).

外務省（2013）：「大学におけるODAの戦略的活 用」(結果概要). http://www.mofa.go.jp/mofaj/ 
gaiko/oda/about/daigaku/sympo_1307/sympo_ 1307.html (2014年10月 2 日閲覧).

外務省国際協力局（2014）：2013年版 政府開 発援助（ODA）参考資料集．外務省国際協力 局, $247 \mathrm{p}$.

科学技術振興機構 (2014): SATREPS 地球の ために，未来のために. http://www.jst.go.jp/ global/ (2014年10月 2 日閲覧).

カッテンディーケ（水田信利訳）（1964）：長崎 海軍伝習所の日々，東洋文庫 26 ，平凡社， 235 p.

国際協力機構 (2015)：大学の皆さまへ. http:// www.jica.go.jp/partner/college（2015 年 8 月 20 日閲覧)。

菅原 繁 (2000) : 水と衛生分野の国際協力：今 後の可能性. 公衆衛生研究, 49, 275-283.

杉田倫明（2010）：水ビジネスは水商売か一水文 科学の立場からの一考察. 都市問題, $101(6)$, $4-10$.

杉田倫明（2012）：水の惑星「地球」の水循環と 水収支. 小笠原正明 - 新井一郎 - 澤村京一 - 杉 田倫明・守橋健二編著，現代人のための統合科 学: ビッグバンから生物多様性まで. 筑波大学 出版会, 190-203.

田中 正（2009）：水文科学とは．杉田倫明・田 中 正 編著，水文科学. 共立出版，1-20. 友松篤信・桂井宏一郎編著（2010）: 実践ガイド 国際協力論. 古今書院, $150 \mathrm{p}$.

橋本毅彦・栗山茂久編著（2001）：遅刻の誕生： 近代日本に打ける時間意識の形成. 三元社, $361 \mathrm{p}$.

藤田 昇・加藤聡史・草野栄一・幸田良介編著 （2013）：環境人間学と地域 モンゴル 草原 生態系ネットワークの崩壊と再生. 京都大学学 術出版会, $685 \mathrm{p}$.

RAISE 研究チーム (2007a)：北東アジア植生変 遷域の水循環と生物・大気圈の相互作用一 RAISEプロジェクトで何が分かったか一，筑 波大学陸域環境研究センター報告，第 8 号別 冊, 1-34.
RAISE (2015): RAISE Database モンゴル国お よび周辺地域の自然環境データベース. http:// raise.suiri.tsukuba.ac.jp/DVD/top/home.htm (2015年 3 月閲覧).

山本一已·山形辰史編（2007）：国際協力の現場 から：開発にたずさわる若き専門家たち. 岩波 ジュニア新書, $206 \mathrm{p}$.

AMPEX/FORSGC/RAISE (2005): Proceedings of the $3^{\text {rd }}$ International Workshop on Terrestrial change in Mongolia. Bull. Terrestrial Environ. Research Center, University of Tsukuba, No. 5 Supplement, 117 p.

Azzaya, D. (eds.) (2005): Terrestrial and Climate Change in Mongolia. Proceedings of the First International Symposium on Terrestrial and Climate Change in Mongolia, Institute of Meteorology and Hydrology, Ulaanbaatar, Mongolia, $178 \mathrm{p}$.

Bomblies, A., Duchemin, J.-B. and Eltahir, E. A. B. (2008): Hydrology of malaria: Model development and application to a Sahelian village. Water Resour. Res., 44, W12445, doi:10.1029/2008WR006917.

FAO (2011): The state of the world's land and water resources for food and agriculture (SOLAW) - Managing systems at risk. Food and Agriculture Organization of the United Nations, Rome and Earthscan, London.

RAISE 研究チーム (2007b) : Rangelands Atmosphere-Hydrosphere-Biosphere Interaction Study Experiment in Northeastern AsianHighlights of the RAISE Project-. Bull. Terrestrial Environ. Research Center, University of Tsukuba, No. 8 Supplement, 73-116.

RAISE 研究チーム (2007c) : ЗҮYн хойд Азийн бэ лчээрийн агаар - ус - шим мандлын харилцан $ү$ йл члэлийн судалгаa (RAISE), туршилт. Bull. Terrestrial Environ. Research Center, University of Tsukuba, No. 8 Supplement, 35-72. Satoh, M. (2015): Recommendations to the 
Government of Egypt from SATREPS Nile Project (2009-2015): For Efficient and Sustainable Agriculture and Better Water Management in the Nile Delta. 15p.

Sugita, M., Azzaya, D., Adyasuren, Ts. and Brutsaert, W. (ed.) (2007): Special Issue of Journal of Hydrology on the Rangelands Atmosphere-hydrosphere-biosphere Interaction Study Experiment in Northeastern Asia (RAISE). Journal of Hydrology, 333 (1).

Sugita, M., Asanuma, J., Tsujimura, M., Mariko, S., Lu, M., Kimura, F., Azzaya, D. and Adyasuren, T. (2008): Rangelands Atmosphere-hydrosphere-biosphere Interaction Study Experiment in Northeastern Asian (RAISE) Data Base, DVD ROMs. Terrestrial Environment Research Center, University of Tsukuba, Tsukuba, Ibaraki, Japan.

UNESCO (2015): Mongolia. http://www. unesco.org/en/university-twinning-andnetworking/access-by-region/asia-and-thepacific/mongolia/ (2015年3月閲覧).

Yamamura, N., Fujita, N. and Maekawa, A. (eds.) (2013): The Mongolian Network: Environmental Issues under Climate and Social Changes. Ecological Research Monographs, Springer, 43-63.

Батжаргал 3. Фужита Н. Яамамура Н. (2012) : М ОНГОЛЫН НҮҮ ДЛИЙН МАЛ АЖ АХУЙ ЭК ОСИСТЕМИЙН СҮ ЛЖЭЭ. Японы Киото хот д ахь Х Ү мүнлэг ба Байгалийн Судалгааны Х элэн (ХБСХ), 576.

(原稿受付 : 2015 年 8 月 18 日)

(原稿受理：2015年 9 月 21 日)

この論文に対する「討論」を2016年4月 30 日 まで受け付けます。 


\section{研究を通した国際協力で求められる水文科学の役割と方法論}

\section{杉田 倫明}

\section{要 旨}

水は生命維持にとって重要であると同時に，環境に影響を及ぼす媒体となりう るため，現実問題の解決にはしばしば水文科学の知識が必要とされる。その結 果，水文科学は日本国内のみならず世界の様々でその研究対象を広げてきた。一 方，研究を介した国際協力という側面に注目すると，技術移転やキャパシティ. ディベロップメントなど相手国からは求められるが研究者にとって本務でない部 分については，必ずしもうまくいっているわけではないように思われる。この理 由として，研究者のこの手の問題に対する経験・知識の不足をあげることができ る。本論は主に著者の個人的な経験と限られた統計データに基づいているため, より網羅的な研究が望まれる。

キーワード : モンゴル, エジプト, 国際協力, 水文科学 